\title{
NUMERICAL SIMULATION OF TIDAL CIRCULATION IN THE PICHAVARAM MANGROVE ESTUARY
}

\author{
Sathyanathan Rangarajan ${ }^{1}$, Deeptha Thattai $^{2}$ \\ ${ }^{1,2}$ Assistant Professor, Department of Civil Engineering, SRM University, Tamil Nadu, India, \\ sathyanathan_r@yahoo.com,vtdeeptha@gmail.com
}

\begin{abstract}
A vertically averaged numerical model is developed using the Surface water Modeling System (SMS) for the Pichavaram Mangrove Estuary to study the tidal characteristics which enables the simulation of the whole water circulation within the water body. The Pichavaram mangrove ecosystem is a complex network of creeks, mangroves and mud flats housed between the Vellar and Coleroon rivers, $15 \mathrm{~km}$ north of Chidambaram, Tamil Nadu, India. A portion of the Coleroon river drains into the mangroves, and tidal flow is through the Coleroon mouth and a small inflow from an inlet in the north. The reduction of freshwater flow over the years has led to a degradation of the mangroves and changes in sedimentation patterns. The results are calibrated against data collected previously. From the simulated results it is noticed that the tidal flow from the Coleroon mouth dominates the entire system. The maximum flood and ebb tide speed reached $0.777 \mathrm{~ms}^{-1}$ and $0.468 \mathrm{~ms}^{-1}$ during monsoon and post monsoon periods, respectively. The tide showed a pronounced asymmetry in mangroves and a 12\% increase in total depth of water with a maximum increase in water level of about 5 $\mathrm{cm}$ is noticed between monsoon and post monsoon conditions. The dominance of ebb tide is noticed due to friction in the mangrove forest, which has resulted in slower flood current and greater tidal asymmetry in the waterway.
\end{abstract}

Index Terms: Pichavaram, Mangroves, Circulation, and Numerical model

\section{INTRODUCTION}

Mangrove forests have iconic status as natural ecosystems that provide services to humans. They function as breeding, spawning, hatching and nursing grounds for marine and pelagic species, and are important in the daily livelihood of local human subsistence communities [1]. Mangrove forests, however, are declining at an alarming rate worldwide. Since 1980, approximately $25 \%$ of mangrove forests have been lost globally and the present mangrove coverage is just over 180,000 sq. $\mathrm{km}$ [2]. The major causes of mangrove degradation and destruction are population pressure, unsustainable production of fish and prawns, mixing of wastewater effluents from urban-industrial areas and oil-spills [3].(Gupta et al 2013). The Indian mangroves contribute significantly toward the shrinking global mangrove reserve with approximately $2.7 \%$ of the world's mangroves existing along the $7516.6 \mathrm{~km}$ long coastline of India [4]. Out of the 39 species of mangroves that are widely encountered over the Indian coast, 37 species are considered under varied degree of extinction risk while 11 mangrove species are considered to be critically endangered [5].. Mangroves grow in the intertidal zone between land and sea. They are frequently inundated by tide leading to water logging and fluctuation in salinity $[6,7$, 8 , 9]. Under high temperature conditions in tropics water logging and salinity problems become worse. Firstly, at low tide, overheating and desiccation is greater, and secondly, through evapotranspiration, any water that remains may become even more highly saline than that of the open sea. At high tide, the warmth of water lowers the oxygen in water [10]. High salinity makes it more difficult for mangroves to extract water from the soil, even though the soils on which mangroves grow are usually waterlogged [11]. In this context the knowledge on hydrodynamics of mangrove creek is essential to know the flow characteristics within a system. A notable characteristic of the hydrodynamics of mangrove creeks is the asymmetry between the flood and ebb water velocity [12]. The hydrodynamics of these estuaries is also crucial to the sediment transport, which modifies the geomorphology of the system and the hydrodynamics itself [13]. In this work, we employ a numerical model to simulate the hydrodynamics in the creeks of Pichavaram, an estuarine type of mangrove wetland situated in between the Vellar and Coleroon estuaries. The results of the hydrodynamic model can be used to investigate the existing flow pattern and tidal regime within the study area and also used as a tool to predict and address the impact of future man-made and natural changes on the health of the tidal waterways.

\subsection{Study Area}

The Pichavaram mangrove wetland is located in the northern extreme of the Cauvery delta, near the mouth of river Coleroon, Tamil Nadu, India, between latitudes $11^{\circ} 20^{\prime}$ and $11^{\circ} 30^{\prime}$ ' north and longitudes $79^{\circ} 45^{\prime}$ and $79^{\circ} 55^{\prime}$ east. Its total area is about 1,350 ha, its many small islands are colonized by 
13 true mangrove species. The Pichavaram mangrove wetland is also rich in fishery resources. Annually about 245 tons of fishery produce is harvested from this mangrove wetland, of which prawns alone constitute 208 tons $(85 \%)$ of the catch. The people belonging to 17 hamlets of five revenue villages utilize the fishery and forestry resources of the Pichavaram mangrove wetlands [14].

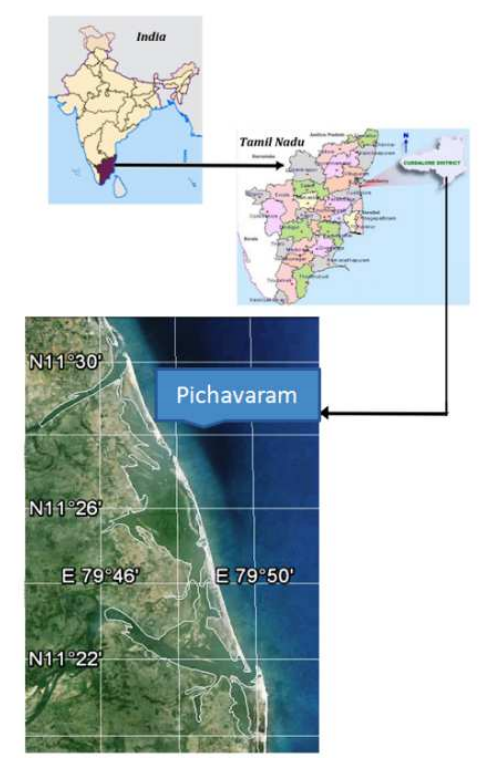

Fig -1: Location map of Pichavaram (Base map from Google Earth)

The entire mangrove vegetation in this area was declared as a reserve forest in 1987. It is connected to the Bay of Bengal in the east and receives fresh water from Coleroon river from the south. Geomorphologically, it is mostly covered by flood plains, sedimentary plains and beach sand [15]. The slope is very mild. Pichavaram receives freshwater mostly during the northeast monsoon season from October to December. Thus the dry season is long, extending from February to September, and correspondingly, the average salinity is also high during the dry season, ranging from 35 to 45 ppt [16]. Pichavaram mangrove has been well studied for its ecology, flora, fauna, water quality, pollution, fishery resources, etc., from early 1970s. But very few circulation studies have been carried out so far in this system despite its ecological and economic importance [17, 18]. A fundamental knowledge of tides and tidal circulation is a prerequisite in understanding the intertidal dynamics and its impacts on the ecosystem. The hydrodynamic environment of Pichavaram is mainly controlled by tidal currents and influenced by runoff from Coleroon river. Our major objective in this study is to explore how tides and runoff affect and drive the circulation in the estuary during monsoon and post monsoon periods.

\section{MODEL DESCRIPTION}

AND

\section{IMPLEMENTATION}

The RMA2 model of the Surface water Modeling System (SMS v11.0) is implemented. The RMA2 model code of the Army Corps of Engineers was initially developed by Norton, King and Orlob[19]. It is a 2D, depth-averaged, finite element hydrodynamic model, with additional pre- and post-processing capabilities. RMA2 computes water surface elevations and horizontal velocity components for subcritical free-surface flow. The Manning's coefficient was used to define friction and eddy viscosity coefficient was used to define turbulence characteristics. Both steady and unsteady (dynamic) problems can be analyzed. The model has been applied to calculate water levels and flow distribution around islands; circulation and transport in water bodies with wetlands; and general water levels and flow patterns in rivers, reservoirs, and estuaries [20]. The $\mathrm{x}$ and $\mathrm{y}$ component momentum acceleration terms and the continuity equation are:

$$
\begin{aligned}
& h \frac{\partial u}{\partial t}+h u \frac{\partial u}{\partial x}+h v \frac{\partial u}{\partial y}-\frac{h}{\rho}\left(E_{x x} \frac{\partial^{2} u}{\partial x^{2}}+E_{x y} \frac{\partial^{2} u}{\partial y^{2}}\right)+g h\left(\frac{\partial a}{\partial x}+\frac{\partial h}{\partial x}\right)+\frac{g u n^{2}}{\left(1.486 h^{1 / 6}\right)^{2}} \\
& \left(u^{2}+v^{2}\right)^{1 / 2}-\tau v_{a}^{2} \cos \psi-2 h \varpi v \sin \phi=0 \\
& h \frac{\partial v}{\partial t}+h u \frac{\partial v}{\partial x}+h v \frac{\partial v}{\partial y}-\frac{h}{\rho}\left(E_{y x} \frac{\partial^{2} v}{\partial x^{2}}+E_{y y} \frac{\partial^{2} v}{\partial y^{2}}\right)+g h\left(\frac{\partial a}{\partial y}+\frac{\partial h}{\partial y}\right)+\frac{g v n^{2}}{\left(1.486 h^{1 / 6}\right)^{2}} \\
& \left(u^{2}+v^{2}\right)^{1 / 2}-\tau v_{a}^{2} \cos \psi+2 h \varpi v \sin \phi=0 \\
& \frac{\partial h}{\partial t}+h\left(\frac{\partial u}{\partial x}+\frac{\partial v}{\partial y}\right)+u \frac{\partial h}{\partial x}+v \frac{\partial h}{\partial y}=0
\end{aligned}
$$

where $\mathrm{h}$ is depth $(\mathrm{m}), \mathrm{u}$ and $\mathrm{v}$ are component velocities along the $\mathrm{x}$ and $\mathrm{y}$ Cartesian coordinates (ms-1), respectively; $\mathrm{t}$ is time ( $\mathrm{s}) ; \rho$ is water density $(\mathrm{kg} \mathrm{m}-3) ; \mathrm{E}$ is eddy viscosity $(\mathrm{kg}$ $\mathrm{m}-1 \mathrm{~s}-1)$; $\mathrm{g}$ is gravity $(9.81 \mathrm{~m} \mathrm{~s}-2)$; a is bottom elevation (m); $\mathrm{n}$ is Manning's roughness ( $\mathrm{s} \mathrm{m}-1 / 3) ; \tau$ is wind stress $(\mathrm{kg} \mathrm{m}-1 \mathrm{~s}-$ 2); $\mathrm{Va}$ is wind speed (ms-1); $\psi$ is angle towards which the wind blows (degrees), counter-clockwise with 0o on the positive $\mathrm{x}$-axis; $\omega$ is the rate of earth's angular rotation (7.29*10-5 s-1); and $\Phi$ is latitude (deg).

\subsection{Materials and Methods}

The only available tidal data within the mangroves is from the M. S. Swaminathan Research Foundation (MSSRF), Chennai, from their project on Mangrove Conservation and Management in the Coastal Wetlands of Tamil Nadu during 1999-2000. They measured the variation of tide levels at 30 minute intervals by installing Aanderaa Self Recording Tide Recorders at six different stations within the estuary. The details of the measurement locations and duration are shown in Fig- 2 and Table-1. These data were also not simultaneously taken and the datums used for the stations appear to be different. 


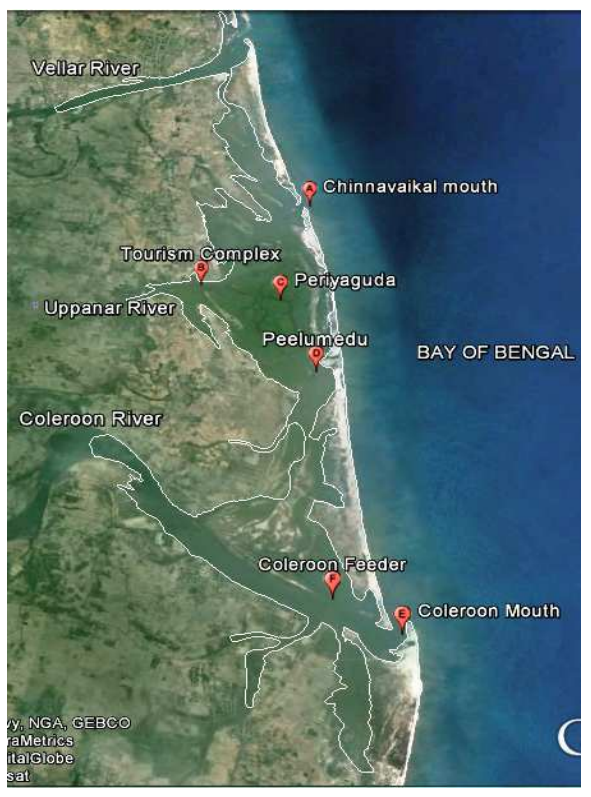

Fig -2: Measurement location of tides

Table -1: Measurement duration of tides

\begin{tabular}{|c|c|c|c|}
\hline \multirow[t]{2}{*}{ Station name } & \multirow{2}{*}{$\begin{array}{l}\text { Measurement } \\
\text { Depth from } \\
\text { surface }(\mathrm{m})\end{array}$} & \multicolumn{2}{|l|}{ Duration } \\
\hline & & From & To \\
\hline Chinnavaikal & $1.0 \mathrm{~m}$ & 21.05 .2000 & 28.05 .2000 \\
\hline $\begin{array}{l}\text { Tourism } \\
\text { Complex }\end{array}$ & $0.5 \mathrm{~m}$ & 14.05 .2000 & 21.05 .2000 \\
\hline Periyaguda & $1.0 \mathrm{~m}$ & 14.05 .2000 & 21.05 .2000 \\
\hline Peelumedu & $1.0 \mathrm{~m}$ & 21.05 .2000 & 28.05 .2000 \\
\hline $\begin{array}{l}\text { Coleroon } \\
\text { Mouth }\end{array}$ & $2.0 \mathrm{~m}$ & 28.05 .2000 & 29.05 .2000 \\
\hline $\begin{array}{l}\text { Coleroon } \\
\text { Feeder }\end{array}$ & $1.0 \mathrm{~m}$ & 28.05 .2000 & 29.05 .2000 \\
\hline
\end{tabular}

\subsection{Digitization and Mesh Construction}

The domain mesh for the estuary was developed by digitizing the area of study from Google Earth, which gave a realistic and real time topographical information. Since bathymetry data for the time period 1999-2000 was not available, an extensive bathymetric study was undertaken in 2013 with the help of hand held GPS covering major stations within the estuary. The open sea bathymetric data was extracted from General Bathymetric Chart of the Oceans (http://www.gebco.net). The model was constructed using the mesh module. The mesh consists of 4841 elements and 10224 nodes with a front width of 377 . The average element measures $7938 \mathrm{~m} 2$ and the element areas range from $193 \mathrm{~m} 2$ to $39365 \mathrm{~m} 2$. The digitized contours were interpolated by the inverse distance weighted method using the nearest five points in each quadrant.

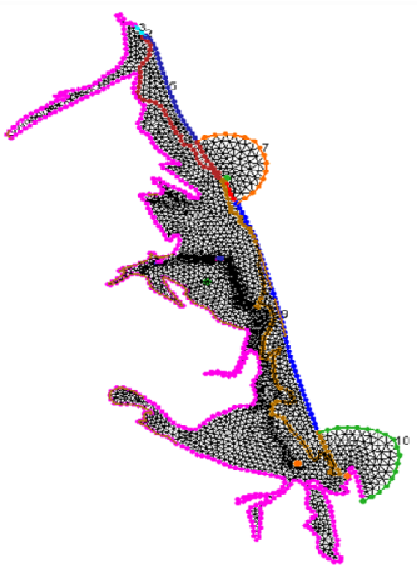

Fig -3: Mesh for the Pichavaram model

During the calibration phase, after extensive experimentation, we set the following parameters: (a) Global roughness value: 0.022, (b) Peclet number: 20 (c) Minimum velocity: $0.3 \mathrm{~m} / \mathrm{s}$ (d) Marsh porosity, Transition range of distribution: 0.6 and (e) Minimum wetted surface area factor: 0.02.

\subsection{Boundary conditions and Model calibrations}

The sinusoidal curve based on the tidal water level obtained from WXtide32 (www.wxtide32.com) in May 2000 was used to force the model at Coleroon mouth and Chinnavaikal mouth. The measured water level data from the three interior stations viz. Tourism complex, Peelumedu, and Periyaguda were used to verify simulation results. Since the available water level data for Coleroon mouth and Coleroon feeder was for only one day and the Chinnavaikal mouth has shifted considerably between 2000 and now, these stations were not considered for calibration. The model was simulated for 30 days with a time step size of $10 \mathrm{~min}$.

\section{RESULTS}

\subsection{Tidal Simulation}

Fig- 4 shows the comparisons between the computed surface elevation and observed values during May 2000. The simulated levels are consistent with the measured values, and the RMS errors after 30 days of simulation are only $0.071 \mathrm{~m}$, $0.078 \mathrm{~m}$ and $0.105 \mathrm{~m}$ at Tourism complex, Periyaguda and Peelumedu, respectively. The model has not captured the extreme peaks of the observed data but it is difficult to calibrate exactly given the scattered nature of the data available for comparison. To analyze the hydrodynamics in the estuary under varying monsoon conditions, two simulations were run, each for a 40 day period and the results for the last 30 days were used. The simulation runs were: (a) Monsoon condition, where tidal flux is imposed at Coleroon and Chinnavaikal mouths and mean river discharge of 300 m3s-1 and $10 \mathrm{~m} 3 \mathrm{~s}-1$ were imposed at Coleroon and Uppanar 
rivers, respectively and (b) Post monsoon condition, where only tidal flux was imposed at the boundary. Time series of hourly tidal velocities and water elevations were extracted for seven locations in the estuary for further analysis. Calculated statistics include maximum and minimum amplitudes, net current speed and net direction.
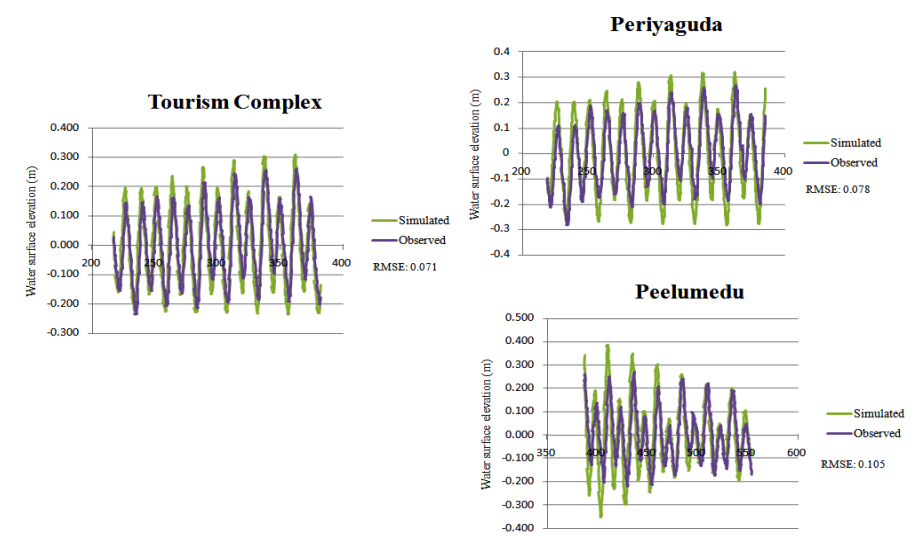

Fig -4: Calibration of the model for May 2000

\subsection{Case (a) Monsoon Condition}

During the monsoon season, river discharge from Coleroon becomes an important forcing function. The river has an average discharge of 1453 cumecs during monsoon, and it also experiences spiked heavy flows intermittently due to flood releases from the Lower Anaicut dam upstream [21]. Table -2 presents the statistics of the modeled water levels and velocities at seven stations.

Table -2: Statistics of water levels and velocities during monsoon period

\begin{tabular}{|c|c|c|c|c|c|c|c|c|}
\hline \multirow{3}{*}{$\begin{array}{l}\text { Nov'99- } \\
\text { Dec'g9 }\end{array}$} & & Coleroon mouth & Peelumedu & Chinnavaikal & Mangroves & Coleroon feeder & Periyaguda & Tourism complex \\
\hline & Lat & 11021'38" & $1102457 "$ & $1102728^{\prime \prime}$ & 11025'26" & $11 \circ 2153^{\prime \prime}$ & $11025^{\prime} 53^{\prime \prime}$ & 11025'49" \\
\hline & Long & $79049^{\prime} 58^{\prime \prime}$ & $79048^{\prime} 29^{\prime \prime}$ & 79047'59" & 79047'41" & $79049^{\prime} 9^{\prime \prime}$ & $79047^{\prime} 53^{\prime \prime}$ & 79046'53" \\
\hline \multirow{4}{*}{$\begin{array}{c}\text { Total depth, } \\
\eta(\mathrm{m})\end{array}$} & Max & 6.191 & 1.694 & 2.95 & 0.286 & 2.707 & 1.803 & 0.896 \\
\hline & Min & 5.056 & 0.682 & 1.793 & 0.025 & 1.604 & 1.06 & 0.33 \\
\hline & Average & 5.595 & 1.156 & 2.348 & 0.066 & 2.117 & 1.359 & 0.495 \\
\hline & Std dev & 0.223 & 0.204 & 0.228 & 0.039 & 0.217 & 0.161 & 0.123 \\
\hline $\begin{array}{l}\text { Net speed, } \\
\mathrm{V}\left(\mathrm{ms}^{-1}\right)\end{array}$ & Average & 0.286 & 0.197 & 0.273 & 0.014 & 0.132 & 0.077 & 0.209 \\
\hline \multirow{2}{*}{$\mathrm{u}\left(\mathrm{ms}^{-1}\right)$} & Max & 0.204 & 0.44 & 0.68 & 0.015 & 0.279 & 0.158 & 0.328 \\
\hline & Min & -0.061 & -0.33 & -0.285 & -0.051 & -0.119 & -0.191 & -0.115 \\
\hline \multirow{2}{*}{$v\left(m s^{-1}\right)$} & Max & 0.72 & 0.335 & 0.375 & 0.021 & 0.126 & 0.026 & 0.014 \\
\hline & Min & -0.297 & -0.271 & -0.103 & -0.044 & -0.233 & -0.012 & -0.018 \\
\hline \multirow{2}{*}{$\begin{array}{c}\text { Tidal level, } \\
\text { (m) }\end{array}$} & $\operatorname{Max}$ & 0.605 & 0.598 & 0.602 & 0.484 & 0.623 & 0.506 & 0.503 \\
\hline & Min & -0.529 & -0.414 & -0.556 & 0.028 & -0.481 & -0.237 & -0.066 \\
\hline $\begin{array}{c}\text { Net } \\
\text { Direction } \\
\left.\text { (towards }{ }^{\circ} \mathrm{T}\right)\end{array}$ & & 322.91 & 347.77 & 319.74 & 68.02 & 329.58 & 7.59 & 12.39 \\
\hline $\begin{array}{c}\text { Flood tide } \\
\left(\mathrm{ms}^{-2}\right)\end{array}$ & Max & 0.748 & 0.553 & 0.777 & 0.026 & 0.306 & 0.16 & 0.328 \\
\hline $\begin{array}{c}\text { Ebb tide } \\
\left(\mathrm{ms}^{-1}\right)\end{array}$ & Max & 0.303 & 0.427 & 0.303 & 0.067 & 0.262 & 0.191 & 0.116 \\
\hline
\end{tabular}

The time series of water levels and velocities for this period are plotted in Figure 5 and Figure 6, respectively.

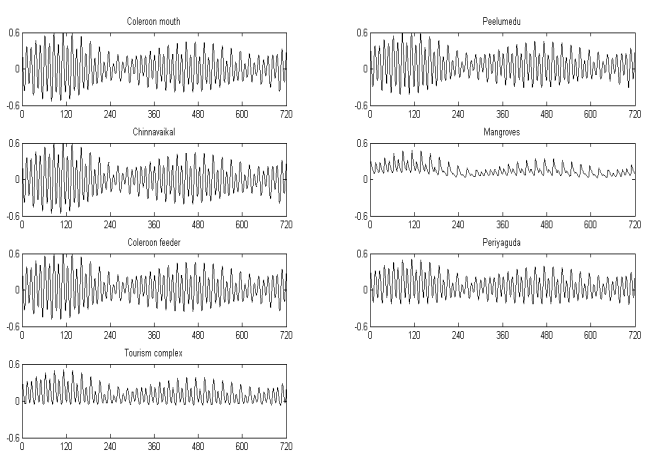

Fig -5: Modeled water level for monsoon condition
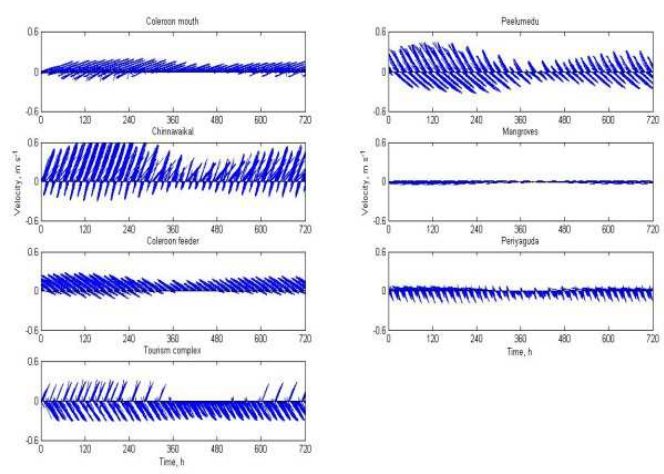

Fig -6: Modeled velocity for monsoon condition

The residual circulation due to river discharge is shown in Figure 7.

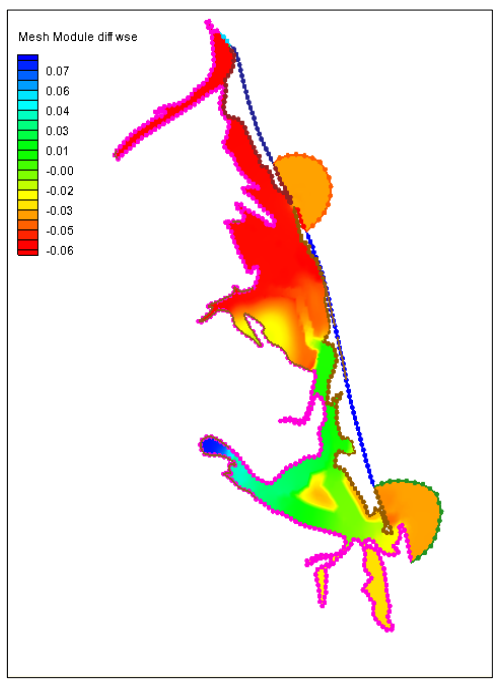

Fig -7: Residual water surface level between monsoon and post monsoon condition 


\subsection{Case (b) Post Monsoon Condition}

During post monsoon season, tide was the only forcing function in the model. Table 3 presents the statistics of the modeled water levels and velocities at seven stations.

Table -3: Statistics of water levels and velocities during post monsoon period

\begin{tabular}{|c|c|c|c|c|c|c|c|c|}
\hline \multirow{3}{*}{$\begin{array}{l}\text { Fcbíl'o- } \\
\text { Mar'oO }\end{array}$} & & Coleroon mouth & Peelumedu & Chinnavaikal & Mangroves & Coleroon feeder & Periyaguda & Tourism complex \\
\hline & Lat & $11021 ' 38^{\prime \prime}$ & $11^{\circ} 24^{\prime} 57^{\prime \prime}$ & $1102728 "$ & $1102526^{\prime \prime}$ & $1122153 "$ & $11^{\circ} 25^{\prime} 53^{\prime \prime}$ & $11^{\circ} 25^{\prime} 49^{\prime \prime}$ \\
\hline & Long & $79^{\circ} 49^{\prime} 58^{\prime \prime}$ & $79^{\circ} 48^{\prime} 29^{\prime \prime}$ & $79^{\circ} 47^{\prime} 59^{\prime \prime}$ & $79^{\circ} 47^{\prime} 41^{\prime \prime}$ & $79^{\circ} 49^{\prime} 9^{\prime \prime}$ & 79.4753" & $79^{\circ} 46^{\prime} 53^{\prime \prime}$ \\
\hline \multirow{4}{*}{$\begin{array}{l}\text { Total depth, } \\
\quad \eta(\mathrm{m})\end{array}$} & Max & 6.121 & 1.624 & 2.899 & 0.218 & 2.631 & 1.745 & 0.835 \\
\hline & Min & 5.151 & 0.654 & 1.906 & 0.015 & 1.646 & 1.062 & 0.205 \\
\hline & Average & 5.596 & 1.114 & 2.363 & 0.059 & 2.098 & 1.345 & 0.448 \\
\hline & Std dev & 0.216 & 0.213 & 0.222 & 0.034 & 0.218 & 0.155 & 0.144 \\
\hline $\begin{array}{l}\text { Net speed, } \\
\mathrm{V}\left(\mathrm{ms}^{-1}{ }^{-1}\right)\end{array}$ & Avcrage & 0.194 & 0.221 & 0.234 & 0.013 & 0.104 & 0.070 & 0.099 \\
\hline \multirow[t]{2}{*}{$\mathrm{u}\left(\mathrm{ms}^{-1}\right)$} & Max & 0.145 & 0.566 & 0.571 & 0.014 & 0.21 & 0.181 & 0.178 \\
\hline & Min & -0.09 & -0.3 & -0.26 & -0.044 & -0.175 & -0.147 & -0.228 \\
\hline \multirow[t]{2}{*}{$\mathrm{v}\left(\mathrm{ms}^{-1}\right)$} & Max & 0.515 & 0.298 & 0.314 & 0.018 & 0.142 & 0.019 & 0.009 \\
\hline & Min & -0.405 & -0.359 & -0.093 & -0.04 & -0.189 & -0.012 & -0.018 \\
\hline \multirow{2}{*}{$\begin{array}{c}\text { Tidallevel, } \\
(\mathrm{m})\end{array}$} & Max & 0.535 & 0.528 & 0.55 & 0.407 & 0.547 & 0.449 & 0.441 \\
\hline & Min & -0.434 & -0.442 & -0.442 & -0.04 & -0.439 & -0.235 & -0.206 \\
\hline $\begin{array}{c}\text { Net } \\
\text { Direction } \\
\text { (towards } " T)\end{array}$ & & 229.37 & 247.11 & 225.29 & 337.7 & 233.16 & 271.51 & 276.03 \\
\hline $\begin{array}{l}\text { Flood tide } \\
\left(\mathrm{ms}^{1}\right)\end{array}$ & Max & 0.535 & 0.640 & 0.652 & 0.023 & 0.254 & 0.182 & 0.178 \\
\hline $\begin{array}{c}\text { Ebbtidide } \\
\left(\mathrm{ms}^{-1}\right)\end{array}$ & Max & 0.415 & 0.468 & 0.276 & 0.059 & 0.258 & 0.147 & 0.229 \\
\hline
\end{tabular}

The time series of water levels and velocities for this period are plotted in Figure 8 and Figure 9, respectively.

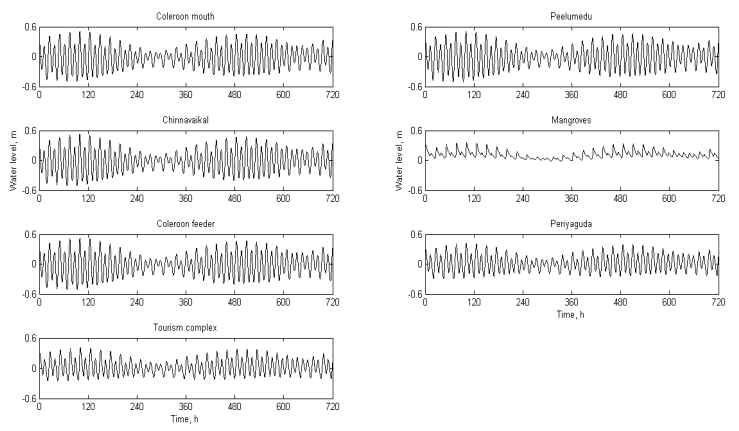

Fig -8: Modeled water level for post monsoon condition
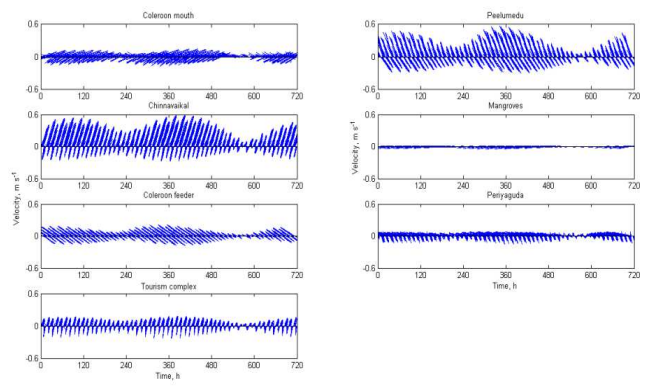

Fig -9: Modeled velocity for post monsoon condition

\section{DISCUSSION}

\subsection{Case (a) Tidal Simulation for Monsoon Condition}

A river discharge of 300 cumecs given at Coleroon increases the velocity in the entire channel. The circulation pattern reveals the dominance of Coleroon river mouth in driving the flow into the estuary. The influence of tidal flow through Chinnavaikal is limited to Tourism complex and a minimum flow is observed to be reaching till Periyaguda.

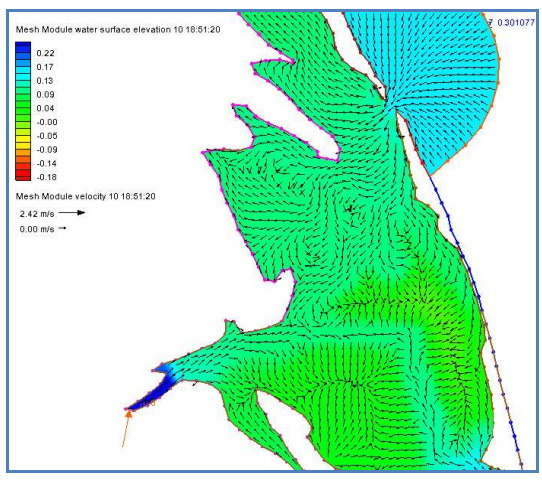

Fig -10: Tidal circulation during monsoon period

An increase in current velocity is noticed at Tourism complex due to the influence of freshwater flow from Uppanar. The flow direction is northwest at the stations located at the eastern side where the tidal impact is predominant (Coleroon mouth, Peelumedu, Chinnavaikal and Coleroon feeder). The flow turns northeast at the other stations (Tourism complex, Mangroves and Periyaguda). The river discharge induces a stronger ebb current velocity of $0.067 \mathrm{~ms}-1$ in mangrove region (Figure 11 and Table 2). The dominance of the ebb tide is due to friction in the mangrove forest and the friction is in turn influenced by the density of the mangrove roots [22]. This results in slower flood current and greater tidal asymmetry in the waterway. The flood currents are much stronger than the ebb currents in most of the stations except mangroves, the duration being shorter in the case of flood than ebb. The magnitudes of currents noticed in Periyaguda is very small and not proportional to the tidal heights observed in the region and are inversely proportional to the depth.

\subsection{Case (b) Tidal Simulation for Post Monsoon Condition}

When the tide is the only forcing function, the analysis of flow into Pichavaram creek system reveals that the stations Coleroon feeder, Peelumedu, Periyaguda and Tourism complex are influenced by the tidal flow from the Coleroon river mouth. The influence of tidal flow through Chinnavaikal mouth is limited to a shorter reach within Periyaguda. 


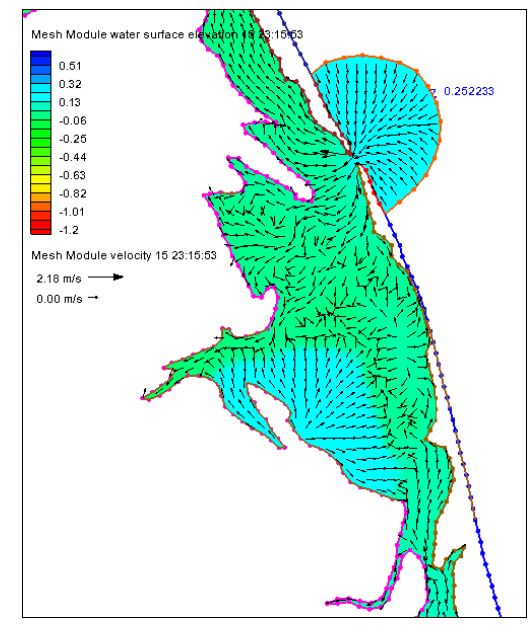

Fig -11: Tidal circulation during post monsoon period

The flow direction, which was northwest during monsoon period, changes to southwest at the stations Coleroon mouth, Peelumedu, Chinnavaikal and Coleroon feeder. The flow turns from northeast to northwest at the other stations (Tourism complex, Mangroves and Periyaguda) (Table 3). The station shown as mangroves here is only a reference station shown for analysis. The magnitude and direction of currents at other places inside the mangroves will vary depending on the location. The water level variability in mangroves is consistent with that of mangroves from other studies; a time lag of 3-4 hours is noticed with reference to the tides given at the boundary (Figure 12). The tide also shows a pronounced asymmetry in mangroves as documented by many researchers $[12,23]$. The ebb tide is lower but with a stronger current velocity of $0.059 \mathrm{~ms}-1$ compared to the flood tide $(0.023 \mathrm{~ms}-$ 1) (Figure 13). This gives a clear indication that the drag forces induced by mangrove trees greatly reduce the flow in the mangrove swamps. The prevalence of shallow depth and the influence of friction maximize the current speed at Chinnavaikal. The influence of ebb tide in Tourism complex is attributed to its shallow depth.

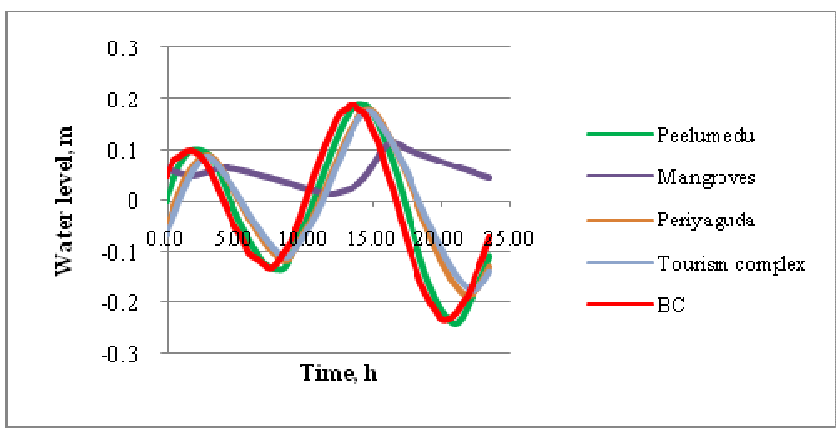

Fig -12: Time lag of simulated tides with the open sea
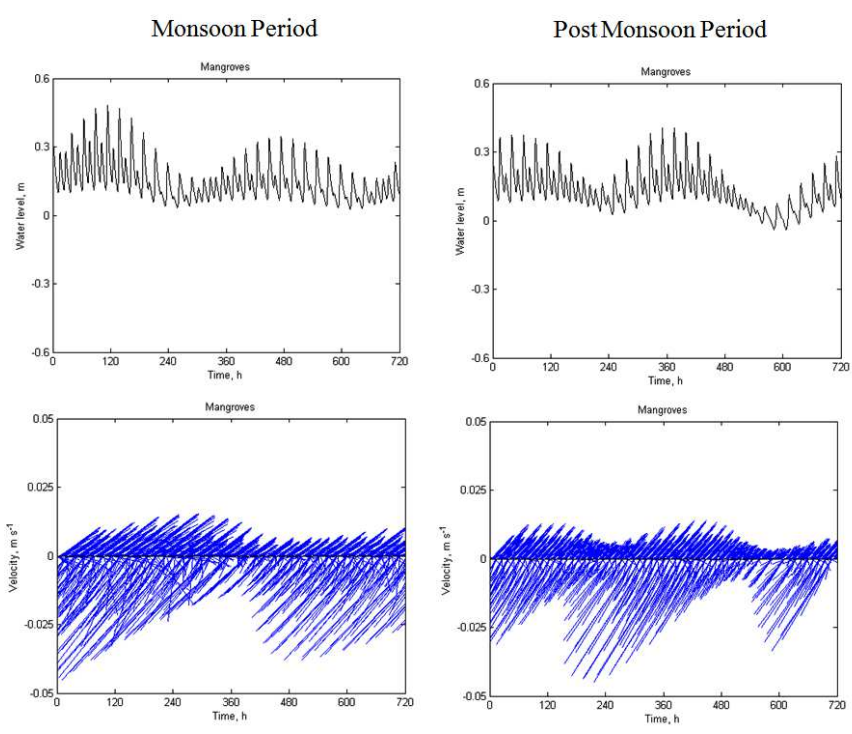

Fig-13: Water level and velocity during monsoon and post monsoon period for mangroves

\subsection{Residual Circulation}

A $12 \%$ increase in total depth of water was noticed in Mangrove station between monsoon and post monsoon conditions. The residual effect of river discharge in the estuary was examined by taking the difference in modeled water surface levels of monsoon and post monsoon periods. An increase in water level of about $5 \mathrm{~cm}$ is noticed between Coleroon river mouth and Periyaguda (Figure 9).

\section{CONCLUSIONS}

In this paper, SMS/RMA2 is employed to establish a twodimensional finite element numerical model to simulate the hydrodynamics in the Pichavaram mangrove estuary. The model fit well with the complicated bathymetry and simulated the character of water surface level and current in the estuary. Based on the computed results, the tide is mainly semidiurnal and the propagation of tide into the creek system reveals that most of the interior stations are dominated by the tidal flow from the Coleroon river mouth and the influence of tidal flow through Chinnavaikal mouth is limited to a shorter reach both in monsoon and pre monsoon periods. The net transport of water is found to be manipulated by the tides during non monsoon season and the influence of river runoff becomes dominant during monsoon period. The tide shows a pronounced asymmetry in mangrove region, with a time lag of 3-4 hours with reference to the tides given at the boundary. A stronger ebb current velocity of $0.059 \mathrm{~ms}-1$ compared to a weaker flood velocity of $0.023 \mathrm{~ms}-1$ is noticed in mangroves during post monsoon period. The river discharge during monsoon period further increases the ebb current velocity in mangroves to $0.067 \mathrm{~ms}-1$ and in turn reduces the magnitude of the tide. This clearly shows that mangrove forests are effective 
in surface wave attenuation and they are the most natural and cheapest way for coastal protection and should be protected and conserved.

\section{ACKNOWLEDGEMENTS}

The authors would like to thank MSSRF for providing the data and are very grateful to Aquaveo for providing license to access SMS/RMA2 model to conduct this research.

\section{REFERENCES}

[1]. Dahdouh-Guebas F, L.P. Jayatissa, D. Di Nitto, J.O. Bosire, D. Lo Seen and N. Koedam (. How effective were mangroves as a defence against the recent tsunami? Current biology, Vol. 15. No.12.

[2]. FAO Forestry Paper 153. Rome: Food and Agriculture Organization of the United Nations; 2007.

[3]. Rajarshi DasGupta and Rajib Shaw (2013). Changing perspectives of mangrove management in India - An analytical overview. Ocean \& Coastal Management 80 (2013) 107-118

[4]. Giri, C., Ochieng, E., Tieszen, L.L., Zhu, Z., Singh, A., Loveland, T., Masek, J., Duke, N., 2011. Status and distribution of mangrove forests of the world using earth observation satellite data. Global Ecology and Biogeography 20, 154-159.

[5]. MoEF, GoI, 2008. Mangroves for The Future: National Strategy and Action Plan, India (Revised Draft).

[6]. Naidoo G, Tuffers AV, von Willert DJ (2002) Changes in gas exchange and chlorophyll fluorescence characteristics of two mangroves and a mangrove associate in response to salinity in the natural environment. Trees Struct Funct 16:140146

[7]. Sengupta A, Chaudhuri S (2002) Arbuscular mycorrhizal relations of mangrove plant community at the Ganges river estuary in India. Mycorrhiza 12:169-174

[8]. Paliyavuth C, Clough B, Patanaponpaiboon P (2004) Salt uptake and shoot water relations in mangroves. Aquat Bot 78:349-360

[9]. Jagtap TG, Nagle VL (2007) Response and adaptability of mangrove habitats from the Indian subcontinent to changing climate. Ambio 36:328-334

[10]. Hogarth, P. (2007) Biology of Mangroves and Seagrasses. Oxford University Press

[11]. Asish Kumar Parida and Bhavanath Jha (2010). Salt tolerance mechanisms in mangroves: a review. Trees 24:199217

[12]. Wolanski, E., Jones, M. and Bunt, J.S. (1980). Hydrodynamics of a tidal creek mangrove swamp system. Australian Journal of Marine and Freshwater Research. 31: 431-450.

[13]. Jerome Aucan \& Peter V. Ridd (2000). Tidal asymmetry in creeks surrounded by saltflats and mangroves with small swamp slopes. Wetlands Ecology and Management 8: 223231
[14]. MSSRF, 2010. Pichavaram mangrove wetland: Situation Analysis. M.S. Swaminathan Research Foundation, Taramani, Chennai, India.

[15]. Balasubramanian, T. and Ajmal Khan, S. 2002. Mangroves of India, State of the art report, Envis Publication series:2, Center of Advanced Study in Marine Biology, Annamalai University, Parangipettai, TamilNadu, India.

[16]. Selvam, V., (2003). Environmental classification of mangrove wetlands of India. Current Science. 84 (6): 25.

[17]. Indomer 1999 -2000. Hydrodynamic study at Pichavaram tidal inlet (Phase I, II, III and IV) for MSSRF, Chennai.

[18]. Deeptha, V.T., and Thandaveswara, B.S., 1998. Diffusion Model to Study Mangrove Hydrodynamics. Proc. Int. Conference on Water Resources Engineering, ASCE: 538543

[19]. Norton, W.R., King, I.P., and Orlob, G.T. (1973). A Finite Element Model for Lower Granite Reservoir, Walla Walla District, U.S. Army Corps of Engineers, Walla Walla, Washington, USA.

[20]. Moustafa S. El-Sammany and Ashraf M. El-Moustafa (2011). Adaptation of Surface Water Modeling System for Sediment Transport Investigations in Lake Nasser. J. Nile Basin Water Science and Engineering Journal. 4(1):71-85.

[21]. Sathyanathan, R., Deeptha, V.T. and Selvam, V., (2009). Assessment of Environmental Flow for a Mangrove Swamp Ecosystem in Tamil Nadu (India). Journal of Environmental Research and Development. 3(4): 1099-1107. [22]. Mazda, Y., Kanazawa, N. and Wolanski, E. 1995. Tidal asymmetry in mangrove creeks. Hydrobiologia 295: 51-58.

[23]. Wu Y., Falconer, R.A. and Struve, J. (2001). Mathematical modelling of tidal currents in mangrove forests. Environmental Modelling and Software. 16: 19-29.

\section{BIOGRAPHIES}

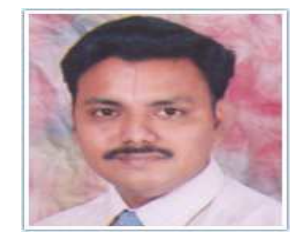

Mr. Sathyanathan R has held his current position as Assistant Professor since 2004. His interest are in numerical modeling, wetland ecosystem, Remote sensing and GIS application in Water resources and Solid waste management.

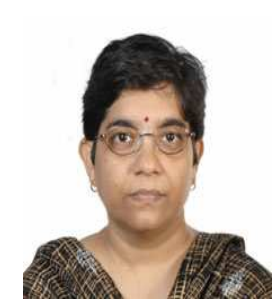

Dr. V. T. Deeptha has been working as Assistant professor working in the Department of Civil Engineering for the past 8 years. She holds Ph.D. in Physical Oceanography. Her interest are in Coastal physical processes, numerical modeling of coastal ecosystem, wetland and mangroves 